\title{
A multi-agent planning support system for assessing the role of transportation and environmental objectives in urban planning
}

\author{
Rachel Katoshevski-Cavari ${ }^{a}$ \\ Technion-IIT \\ Theo Arentze \\ Technical University Eindhoven
}

\author{
David Katoshevski \\ Ben-Gurion University \\ Harry Timmermans \\ Technical University Eindhoven
}

\begin{abstract}
This paper analyzes 12 city plans that were developed based on environmental-sustainability indicators using a multi-agent model. The plans are based on three city forms and four types of city scenarios, each representing a different planning concept. The environmental indicators concern pollution from transportation, while the sustainability aspects relate to accessibility to facilities. The model supports planners in identifying the best city form considering the selected performance criteria. In this case study, a compact city form, coupled with mixed land-uses, performed best.
\end{abstract}

\section{$1 \quad$ Introduction}

The strengths and nature of the relationships between transportation, land use, and the environment are well documented (Hall 1996, for example). These relationships are key factors in developing a sustainable built environment. However, the fundamental question remains: How can planners strike a balance between these three aspects in order to develop an attractive built environment where travel is minimized and environmental quality attained?

When considering the connection between the first two aspects, land use and transportation, Hall (1996) claimed that planners should consider these two factors as meshed together into a highly fragile combination. That is to say, connecting and harmonizing land uses and transportation so that both elements will coexist in a good manner is not easily accomplished. Hence, when a planner looks at these aspects, he must do so in a delicate manner to create a win-win situation.

In dealing with the connection between land use and transportation, O'Meara (1998) argued: "The physical structure of a city cannot change overnight, but decisions about transportation and land use will determine how it is shaped over time. By building roads, rail lines or bike paths, city planners decide not only how people will move around, but also where the accessible and desirable buildings will be...” (p. 11). Newman and Kenworthy (1992) elaborated on the connection between land use and environmental aspects: "The great challenge in our cities is to protect individual freedom in locating land uses and to provide access to them, while maintaining the public qualities of clean air, safe streets, and attractive public spaces" (p. 360).
Although the question concerning the optimized planning form still exists (a question which has a long history in planning research literature), it is commonly agreed that city structure and planning can help to develop a sustainable built environment. That is, urban planning can play an essential role in creating sustainable relationships between land use, transportation, and environment.

The aim of our study was to investigate the impact of city form and planning ideas/scenarios on transportation, land use, and the environment in developing a sustainable built environment. In other words, can urban planners formulate a planning form/scenario that will reduce travel and consequently pollution while simultaneously creating a sustainable built environment by suggesting the optimal land-use and facility (such as kindergarten, shops, medical centers, etc.) distributions?

The multi-agent model we have developed can be used as a decision-support tool to simulate the impact of different urban forms on activity-travel patterns and the evolution of land use. The results are then linked to pollution/emissions. The advantages of the multi-agent approach are twofold. First, it allows us to simulate complete daily activity patterns of individuals at the required level of detail. Micro-simulation (such as the multi-agent model) is the only feasible way to reproduce the variability in activity-travel patterns that exists in the real world.

The second advantage of the multi-agent approach is that it allows us to simulate the behavior of suppliers (individuals and organizations engaged in supplying or serving the facilities) while taking into account all interactions that result from competition among those suppliers and response to demand (interactions with individuals). The application of the model

${ }^{a}$ krachel@bgu.ac.il 
to the fundamental principles of the city form implies that this study substantially differs from other models that concentrate on the impact of different short- and long-term policies such as parking and congestion fees, ridesharing, car ownership, or changing workplaces. Our model, on the other hand, concentrates on the planning in practice: it deals with planning form/ scenarios as a tool for reducing travel and hence city pollution. As Newman and Kenworthy (1992) note, "The role of the planner is to help to choose the infrastructure around which the city and its marketplace can adjust. This choice needs to consider such issues as air quality and sprawl, questions of urban places and neighborhoods and community, and the vitality of centers and sub-centers. All of these have an impact on economic performance but are much more than just marketplace choices. They are choices about the preferred city" (p. 360).

The model/decision support tool (Arentze and Timmermans 2000) incorporates these aspects mentioned by Newman and Kenworthy (1992) and is thus potentially useful in the context of dealing with the preferred city.

The focus of this paper, however, is not on the model per se, but rather on its application to 12 city scenarios for 150,000 people, presented as a master plan. The 12 versions are based on three city forms and four planning concepts (detailed later). These different city scenarios are compared according to a set of performance indicators. It should be noted that we are analyzing city forms from a more fundamental perspective and not an existing city.

In the course of this paper, we will discuss aspects of city pollution and traveling in the city, followed by a description of the model and the developed planning scenarios and city forms. Finally, the results of the simulations will be presented and discussed.

\section{Travel in the city and pollution}

Over the past several decades, travel within and around cities has become significantly greater. Preimus (1999) claims that the living climate in cities is under great pressure due to an increase in pollution and the lack of open green areas. According to the Dutch National Institute of Public Health and Environment Protection, traffic flows in and around cities are causing various environmental problems: acidification (by car emissions), disturbances (noise, smell, and accidents); fragmentation (of animals' habitats), changes in climate, and waste. Several of these environmental issues are linked to health effects that can arise due to exposure to gasses and particles emitted from vehicles.

The environmental problems of cities are seen to be linked fundamentally to poor design of the urban fabric. In fact, Dutch people have lower levels of satisfaction with housing and the living environment in cities than elsewhere (Preimus 1999). Evidence of this dissatisfaction may be seen in the fact that a positive relationship was found between living in a compact city and tending to be more environmentally concerned. This relationship is partially explained as an outcome of restricted car-based mobility (de Nijs et al. 2004; Geurs and van Wee 2006). The above research also indicates that a major health problem originated from pollution. O'Meara (2001) translated this health problem into a death rate and claims that air pollution from motor vehicles can kill more people than car accidents.

What makes the trade-off between transportation development and the environment all the more complex is the fact that pollution created in the city is not a local (inner city) problem, but a global one since pollution extends far beyond city borders. Hence, the benefits of healthy cities are regional, national, and global (O'Meara 1998).

Several researchers focus on travel behavior as a result of the increase in traveling, the growing complexity of travel patterns, and the desire to understand the planning possibilities for changing travel patterns within a city. Moreover, travel distance within a city is regarded as a key parameter with respect to the urban environment (see, for example, Newman and Kenworthy 1989 and Stone et al. 2007). Common to these studies is the understanding that in addition to the traveling "price," an increase in transportation/mobility options lies at the core of urban growth management (Waddell 2002). Therefore, massive investments in transportation facilities must be made in an effort to support greater progress in efficiently moving people and goods (Forkenbrock and Schweitzer 1999). These transport-behavior studies focus on a variety of questions. How is travel behavior affected by new information and communication technologies? How does land use and growth management affect travel behavior? How much travel is induced as a result of new infrastructures? How do travelers respond to auto restraint policies?

Activity-based travel demand models as a tool for modeling behavioral responses to the issues embodied in these questions have been estimated and applied in various studies (Kitamura et al. 1996; Rossi and Shiftan 1997; Gunn and Van der Hoorn 1998; Shiftan 1999; Algers and Beser 2000; Salvini and Miller 2005; Shiftan 2008; and Katoshevski-Cavari et al. 2009). A common hypothesis is that different policies-including the encouragement of people to live in higher-density residential areas, mixed land-use, transit accessibility, and pedestrian friendliness - create an environment where people drive less (Cervero 1989). This reduction in traveling may result from fewer trips, shorter trips, or shifting from single- 
occupancy vehicles to public transportation, walking, and/or cycling. Cervero and Kockelman (1997), Newman and Kenworthy (1989 \& 1999), Holtzclaw (1990), Frank and Pivo (1994), Kitamura et al. (1997), Badoe and Miller (2000), and Roorda et al. (2009) are examples of studies that assume that living in higher density neighborhoods contributes to the reduction of the motorization level. These assumptions have led some regions to try and implement such policies, including transit-oriented development, mixed land use, and different concentration schemes. Bagley and Mokhtarian (2000) provide an overview of early empirical studies of these policies and their effect on transportation

Although there is a large body of research claiming to have found positive evidence of the effect of higher-density neighborhoods in reducing motorization levels, there is at least an equal number of studies showing no or little influence of the built environment on travel behavior (Handy 1996; Kitamura et al. 1997; Boarnet and Sarmineto 1998; Crane and Crepeau 1998). There are also doubts as to whether land-use configuration itself affects travel patterns or whether people with dissimilar travel behavior preferences select different types of neighborhoods - what is often referred to as a "self-selective" process (see, for example, Dunphy and Fisher 1996; Pontes de Aquino and Timmermans 2010). In brief, while there is no consensus regarding the effect of urban form on travel behavior, there is some consensus that our understanding of the effect of the various planning policies on travel behavior is still limited.

The extension of this line of research dealing with city structure and travel behavior to include pollution is less well developed. Marquez and Smith (1999), discussing the effect of four possible future city scenarios, found that corridor-type development (development along key transportation routes) and compact-type (increased densities in central city areas) scenarios caused a significantly greater decrease in pollution than the business as usual scenario.

Along with our discussion concerning the possible influence of different planning policies, it should be understood that good location choices for houses, workplaces, and facilities are essential. In this research project, we therefore study the combined impact of city forms and planning ideas to better understand the relationships between these two aspects and to enhance the possibilities of creating a sustainable city in terms of activity-travel patterns, pollution, and the distribution of land uses and facilities.

Now we move to the description of the model as a basis for the discussion concerning the planning and for the scenarios included in the study.

\section{The multi-agent system}

The model used here is a multi-agent planning support system that was employed in developing city plans. This model is described here briefly. For a more detailed presentation, see Arentze and Timmermans $(2000 ; 2007)$ and Katoshevski-Cavari (2007). Here we focus on the model's first stage: the suitability function responsible for the land-use map. The other stages are only theoretically explained.

The basis of this model is the assumption that urban dynamics are driven by the decisions of at least three groups of actors: (1) the planning authority, (2) supplier agents, and (3) individuals and households. The assumption is that the behavior, decisions, and interaction of these three groups drive the development of the built environment.

The system comprises several stages and consists of coevolving models for each group. That is, the multi-agent system includes three sub-models, each focusing respectively on: (1) land use, (2) facility location, and (3) facility use. These sub-models generate city maps that present land use and the location of facilities. The input data is based on people's preferences (based on a conjoint study) and observed activity-travel patterns (based on a time-use survey). For a conjoint study and time-use survey, see Katoshevski and Timmermans (2001) and Katoshevski-Cavari (2007).

\subsection{The land-use model: the suitability function}

Determining the suitability of an allocation in the context of the land-use allocation process is based on a suitability function. This part of the system is carried out by the planning authorities and, in our case, based on learning about people's preferences (conjoint study, detailed later). The function is defined by the following equations,

where:

$$
\begin{gathered}
Z_{l g}=\sum_{i} W_{i}^{g} \sum_{j} x_{i j}^{g} \chi_{i j}^{g}(I)+\sum_{l \in G} Z_{g h} \chi_{h}(I) \\
\chi_{i j}^{g}(I)= \begin{cases}1, & \text { if } c_{i j-1}^{g} \leq d_{i}(I)<c_{i j}^{g} \\
0, & \text { otherwise }\end{cases} \\
\begin{array}{ll}
\text { is the exhaustive set of land-use } \\
\text { types } g, h \in G
\end{array} \\
\begin{array}{ll}
\text { is an index of land-use types } \\
\text { extended with city center and main } \\
\text { roads } \\
\text { is an index of cut-of-points used to } \\
\text { define distance intervals }
\end{array} \\
\text { is an index of cells }
\end{gathered}
$$




\begin{tabular}{|c|c|}
\hline$z_{l g}$ & $\begin{array}{l}\text { is the suitability of land } \\
\text { characteristics of cell } l \text { for } g\end{array}$ \\
\hline$w_{i}^{g}$ & $\begin{array}{l}\text { is the weight of distance to land } \\
\text { use/center/road } i \text { for } g\end{array}$ \\
\hline$x_{i j}^{g}$ & $\begin{array}{l}\text { is a suitability score assigned to the } \\
j \text {-th level of distance to } i \text { for } g\end{array}$ \\
\hline$z_{g h}$ & $\begin{array}{l}\text { is the suitability of presence of land } \\
\text { use } h \text { adjacent to } g\end{array}$ \\
\hline$\chi_{b}(1)$ & $\begin{array}{l}\text { equals } 1 \text {, if land use } h \text { is adjacent to } \\
1 \text { and } 0 \text { otherwise }\end{array}$ \\
\hline$d_{i}(1)$ & is the distance of $l$ from $i$ \\
\hline$c_{i j}^{g}$ & $\begin{array}{l}\text { is the } j \text {-th cut-off point for distance } \\
\text { to } i \text { defined for land use } g\left(c_{i 0}=0 \text {, }\right. \\
\left.c_{i 6}=\infty\right)\end{array}$ \\
\hline
\end{tabular}

As described in the above equations, the suitability of a cell ( $L$ ) for a particular land use $(g)$ in this model is assumed to depend on three factors. First, accessibility to main roads, to the city center, and to specific land-use categories ( $h$ ) are measured as a minimum distance across all other cells in the plan area that contains land-use h. Second, adjacency (land use in neighborhood cells) refers to any direct negative or positive effect one land use may have on another adjacent land use (caused by noise, traffic load, decreased visibility, etc.). Adjacency involves the four direct neighboring cells and four diagonal ones. Finally, land characteristics such as slope and soil may have an influence. It is noted that, given the purpose of our analysis, this latter set of factors is not considered here. The land-use map is developed using an allocation algorithm (Katoshevski-Cavari 2007). After the land-use map is finalized, the system "creates" population (the target population for the developed city) and then plots facilities.

\subsection{The facility location and use model}

The facility is determined in the system in two stages. First, the facility location model determines the number, type, and location of facilities that emerge from decisions by agents. Agents are the individuals and organizations engaged in supplying or serving the facilities. We refer to nine types of facilities: daily and non-daily shopping facilities, education facilities (two categories), medical services, leisure time facilities, personal service facilities, sports, and parks. Within each category there are several subclasses. Agents evaluate candidate facility locations in terms of the number of visitors a (new) facility would attract in a given time period (e.g., in the course of a day) based on a catchment area analysis. For each facility type, the system implements an agent that is concerned with developing and maintaining a network of facilities. Thus, a supplier agent incorporates methods to conduct market analysis and to decide about locations. For further information, refer to previous studies by Arentze and Timmermans (2007) and KatoshevskiCavari (2007).

The result of this first stage is a land-use map denoting facilities. However, at this stage, agent decisions about location are based on limited information about users. User behavior is estimated according to a number of assumptions regarding the frequency of activities, normative expenditures, penetration rates, strength of the competition, etc. Uncertainty exists concerning the way the demand will actually be allocated across supply locations by individuals. The actual facility use will be revealed by the facility use model, which is the second stage in facility determination in the system.

The facility use model is based on individuals and households (the third group of actors) who conduct their activities in the planned area and determine the actual needed size and feasibility of facilities. In the multi-agent system, agents schedule and implement their activities on a daily basis using the facility use model. A modified version of Albatross (Arentze and Timmermans 2000), a model of activity-scheduling behavior, is used to simulate the generation and implementation of daily activity-travel patterns. The version of the model that is implemented in this study is estimated based on an Israeli national time-use dataset of the Israeli Central Bureau of Statistics (CBS 1995). The model predicts, for any given day and individual, a sequence of activity episodes with associated trips on a continuous time scale while taking into account temporal constraints, some socio-economic variables, the day of the week, and spatial variables (location and size of facilities). For more information, see Katoshvski-Cavari (2007).

As a consequence of this process and the exploitation of the facilities by individuals (adults and children), the actual demand size will be known. Based on this information, the supplier agents then reevaluate the performance of their developed facilities and consequently decide whether to close or resize facilities. Facility adaptations will have an impact on the spatial choice behavior of individuals. Therefore, after some time, the supplier agents again consider whether adaptations are needed. These adaptation cycles are repeated until convergence between users and facilities is obtained.

This finalizes the whole process of the development of the built environment. The outcome is a map that includes the land use and facilities that are relevant and adapted to the targeted population. This final map can be evaluated based on the performance indicators defined in the system. 


\subsection{Evaluation criteria}

To address the environmental-sustainability issue, we include several specific aspects. The mobility aspects are represented by total city travel per day across all facilities by the population and the number of trips. For each activity type (at the subclass level) the model determines the distance traveled (i.e., the straight-line distance in meters for each trip conducted for the activity type) and the number of trips per day. These two issues - total travel distance and the number of trips - are our first two measures. The total travel distance simply implies that in general there is an emission rate per meter of travel that can be taken as the average rate for various types of vehicles. The second measure, the number of trips, implies that a high number of trips results in more polluting emissions due to more ignition actions of vehicles and time during which the vehicle is not in motion. Hence, a lower number of trips is preferred. The next sets of indicators reflect the accessibility, which reflects the ease of access to facilities, or the convenience of moving from the home location to different facilities. The number of facilities in different distance categories and the distance to the first- and second-nearest facilities are considered fundamental for a sustainable plan.

\subsection{The population}

The model is based on people's preferences and observed activity-travel patterns. The input population data for the activitybased travel demand model is based on a synthetic population, derived from statistical data. For each Housing cell, the system draws as many individuals from the sample as the size of the fraction of the population residing in the cell. The activitybased travel demand model, Albatross (Arentze and Timmermans 2004), was adjusted to the available Israeli time-use survey (CBS 1995), consisting of a sample of 3082 people aged 14 years and older living permanently in Israel. The sample includes Jerusalem, Tel-Aviv, and Haifa, the country's largest cities, and another 83 smaller cities and settlements (Jewish and non-Jewish).

\section{$4 \quad$ The scenarios}

As was noted earlier, the study evaluates 12 city plans, which are based on four defined planning ideas/norms (planning scenarios) and three city forms (which differ in their road structure).

\subsection{The planning scenarios}

Four planning scenarios are considered in this study. Each one of these four scenarios deals with distinctive planning concepts/ideologies.

\subsubsection{Recreation City}

This scenario involves the distribution of city-level Recreation cells. According to this scenario, the city will include several parks, distributed around the city, instead of one main central park. The main issue of this scenario is the distribution of the Recreation cells instead of concentrating them in one large park.

\subsubsection{Nature City}

This scenario denotes a city with "green lungs." The idea of this scenario is to develop a city that will include several Nature cells. These green (Nature) areas should be large enough to offer city residents several significant open places within the city texture that can be used for leisure activities. The planning dilemmas in this scenario focus on the problems associated with creating a green environment and the drawbacks to the city such as the transportation/accessibility "price."

\subsubsection{Mixed City}

This type of scenario deals with mixed land uses. Accordingly, this scenario supports a land-use mix of Commercial cells, Housing, and High-Tech Industry. In principle, the idea behind this scenario is that in order to create a more compact development with an efficient distribution of facilities and reduced reliance on transportation, land uses should be developed in close proximity with one another. This scenario deals with the basic planning question of how to create a compact, efficient built environment.

\subsubsection{Separated City}

This type of scenario posits a city based on two types of living areas: high-density Housing, which includes apartment buildings, and low-density Housing, consisting mainly of detached and row houses. The assumption is that in the high-density areas, in contrast to low-density zones, facilities should be more accessible so that residents will be less dependent on traveling for conducting their various activities. The planning focus of this scenario is the question of whether it is possible to plan a city which offers an area of a comparably low density but with appropriate facility dispersal. Such a city might be an appropriate alternative for those looking for detached or semi-detached housing in a suburban development.

\subsection{City forms/road structures}

As mentioned above, we base our set of city form scenarios on previous studies. See, for example, Marquez and Smith (1999), 
who presented the influence of urban form (the road network) on spatial evolution.

\subsubsection{Basic City}

In this form, two main roads intersect at the center of the planned area, forming an " $\mathrm{X}$ " shape (see Fig. 1). This layout is intended to produce a spread-out, non-dense city whose main focal point is the center, although local neighborhood centers may also be developed along the roads. Housing should develop outward from the center along the roads, creating "fingers" of development radiating from the center but leaving undeveloped green areas between the roads. Since this structure imposes very limited development constraints, it is termed the Basic City in this study.

\subsubsection{Corridor City}

In this form, two axial roads are added to those of the Basic City form. Intersecting at the center of the area, they divide the city into eight sections. This road layout should produce a drastic increase in overall city density since development may be expected to spread outwards from the center along the roads. In this Corridor City configuration, a strong focal point should emerge at the center, but some neighborhood centers may also be developed along each road (Fig. 1).

\subsubsection{Connected City}

This form envisions adding to the Basic City layout several circular main roads that divide the city into sections surrounded by roads (see Fig 1). Such a layout is likely to result in a more constrained development and the emergence of a compact city.
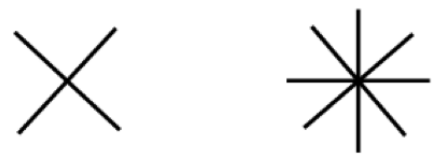

Basic

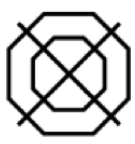

Connected
Figure 1: The three city forms.

\section{$5 \quad$ The 12 city plans}

\section{$5.1 \quad 5.1$ The settings}

We now describe the development and outcome of 12 city plans. First, the land-use input and the main aspects (the suitability parameters) of each planning idea/scenario are described. Common to all planning scenarios are the size and characteristics of the population and a representation of the city area in terms of grid cells. The total number of cells for the whole study area (and for the specific land-use categories) are the same in all scenarios. The planning scenarios are specified in terms of a set of suitability parameters that differ for various planning concepts/norms and the road network structure of the city.

\subsection{Land-use and population settings}

Seven land-use categories were distinguished: (1) Housing high density (Housing- $H$ ), (2) Housing low density (Housing- $L$ ), (3) Industry high tech (Industry-H), (4) Industry low tech (Industry-L), (5) Commercial, (6) Recreation, and (7) Nature. The plan area consists of a regular grid of 2500 cells, each cell being 125 meters by 125 meters in size, divided as follows: 760 cells for Housing- $H$, 400 cells for Housing- $L$; 96 cells for Industry- $H$; 96 cells for Industry- $L$; 96 cells for Commercial land use; 80 cells for Recreation; and 972 cells for Nature. The central business district is located in the geographical center of the city. The total size of the area and proportional land-use requirements are derived from an anticipated population size of 150,000 people and planning standards. The size of a cell was determined such that it is small enough to accurately represent facilities and not so small as to cause excessive computation times.

In this application, the total number of households per cell equals 92 for high-density Housing cells and 39 for lowdensity Housing cells. These numbers are based on the assumption that, on average, a house occupies $210 \mathrm{~m}^{2}$ and 500 $\mathrm{m}^{2}$ in high-density and low-density cells, respectively. A household on average includes 1.24 adult members. The number of workers (in full-time equivalence) is calculated based on the following ratios: two workers per high-tech industry facility, one worker per low-tech industry facility, and 2.5 workers per commercial facility. The simulation is based on a sample fraction of 10 percent of the population. We account for a sample of the population as a case study for establishing our tool. The reason why we use a sample (of 10 percent) rather than the full population is to reduce computation time. It is not necessary to simulate a full population as a sampling fraction such as this provides the same results.

\subsection{The land-use model settings/the suitability parameters}

The initial land use distribution in the system is based on suitability parameters that are defined as input for each of the four planning scenarios. The suitability parameters are summarized in Table 1. It is important to note that this stage, which deals with the development of the parameters for the model to create the land-use map, is completed by the planner based on the specific planning idea (each one of the four included in 
the study), the planner's knowledge, and a conjoint study. The conjoint study, conducted in eight Israeli cities, studied residents' preferences concerning different aspects of their built environment—-such as distances (walking or driving) to various facilities (shopping areas, kindergarten, or work) - their homes (size, kind of dwelling, etc.), and their neighborhood (Katoshevski and Timmermans 2001). The outcome of this stage is an initial land-use map that serves as the starting spatial configuration of land use and transportation for the multi-agent model.
In Table 1, the cut-off points refer to the distance range to a certain (other) land use, main road, and city center divided by six intervals; the range is between 0 to $1250 \mathrm{~m}$. Suitability scores are a score for each distance interval, where 5 is the maximum. Weight refers to the weight of each interval, 5 being the maximum. Adjacency scores include a bonus or penalty for land use to exist in one or more of the eight neighborhood cells; 10 is the maximal score.

Table 1: The four scenarios and the parameter settings for developing land uses.

\begin{tabular}{|c|c|c|c|c|}
\hline \multirow[t]{2}{*}{ Planning Ideas } & \multicolumn{4}{|l|}{ Setting Parameters } \\
\hline & Cut-off Points & Suitability Scores & Weight & Adjacency Scores \\
\hline Recreation City & $\begin{array}{l}\text { Housing to Recreation: } 200 \mathrm{~m}, 400,600 \text {, } \\
800 \\
\text { Recreation to Housing: } 100 \mathrm{~m}, 200,300 \text {, } \\
400\end{array}$ & $\begin{array}{l}\text { A monotonically decreasing function } \\
\text { of distance }\end{array}$ & 5 & $\begin{array}{l}\text { Housing (both kinds) to } \\
\text { Recreation: } 10 \\
\text { Recreation to Housing- } H \text { : } \\
\text { a score of } 10\end{array}$ \\
\hline Nature City & Housing to Nature: $200 \mathrm{~m}, 400,600,800$ & $\begin{array}{l}\text { A monotonically decreasing function } \\
\text { of distance regarding all land uses }\end{array}$ & 5 & $\begin{array}{l}\text { Housing to Nature: } 5 \\
\text { Nature to Housing- } H: 5 \\
\text { Nature-Nature: } 10\end{array}$ \\
\hline Mixed-use City & $\begin{array}{l}\text { Housing- } H \text { and Housing- } L \text { to Commercial: } \\
200 \mathrm{~m}, 400,600,800 \\
\text { Commercial to Housing- } H \text { : } 400 \mathrm{~m}, 600 \text {, } \\
800 \\
\text { Commercial to Housing- } L: 500 \mathrm{~m}, 1000 \text {, } \\
2000 \\
\text { Industry- } H \text { to Industry- } H \text { : most preferred } \\
\text { distance between } 100 \text { to } 500 \mathrm{~m} \\
\text { Industry- } H \text { to Industry- } H \text { : preferred } 500 \\
\text { to } 1000 \mathrm{~m}\end{array}$ & $\begin{array}{l}\text { Housing- } H \text { and Housing- } L \text { to Com- } \\
\text { mercial: A monotonically decreasing } \\
\text { function of distance } \\
\text { Housing- } H \text { and Housing- } L \text { to } \\
\text { Industry- } H \text { : a decreasing function of } \\
\text { distance } \\
\text { Commercial to Housing- } H \text { : decreas- } \\
\text { ing until } 800 \mathrm{~m} \text { and zero thereafter } \\
\text { Industry- } H \text { to Housing: a decreasing } \\
\text { function of distance }\end{array}$ & $\begin{array}{l}\text { Housing to Industry- } H \\
\text { and Industry- } H \text { to Hous- } \\
\text { ing: } 4 \\
\text { Housing to Commercial: } 5 \\
\text { Commercial to Housing- } \\
H: 5 \\
\text { Commercial to Housing- } \\
L: 2\end{array}$ & $\begin{array}{l}\text { Housing- } H \text { to Commer- } \\
\text { cial and Commercial to } \\
\text { Housing- } H \text { : score of } 5\end{array}$ \\
\hline Separate City & $\begin{array}{l}\text { Housing-to Housing (all kinds): } 100 \mathrm{~m} \text {, } \\
200,300,400,500\end{array}$ & $\begin{array}{l}\text { A decreasing function of distance, } \\
\text { and zero from } 500 \mathrm{~m} \text { and on }\end{array}$ & $\begin{array}{l}\text { Housing to its same kind: } \\
5 \text {; to the other kind: } 2\end{array}$ & $\begin{array}{l}\text { Housing- } H \text { to Housing- } \\
H \text { and Housing- } L \text { to } \\
\text { Housing- } L \text { : score of } 10\end{array}$ \\
\hline
\end{tabular}


1.The Recreation City_-As this scenario deals with the spread of Recreation areas in the city in addition to one large Recreation cell cluster, the suitability parameters are determined so that preferences are shown for short distances between the Housing and Recreation cells. The cut-off points for Housing to Recreation are $200 \mathrm{~m}, 400,600,800$; the cut-off points for Recreation to Housing are $100 \mathrm{~m}, 200$, 300,400 . The suitability scores are presented in a decreasing order ( 5 being the highest score and 1 the lowest), supporting the preference for short distances between Housing cells and Recreation cells. The weight of 5 (the highest score) indicates the importance of this setting. Since the suitability scores are multiplied by the weight score, these high values for closer distances mean that the system will distribute land-use cells for Housing and Recreation at a close distance. The adjacency scores refer to the bonus or penalty if a specific land-use exists in one or more of the eight neighboring cells. The highest score in this category is 10 , indicating a very significant bonus for Housing to neighbor Recreation cells and vice versa. The total score, including the cut-off points, suitability scores, and weight score as well as the adjacency scores, emphasizes the idea of this planning scenario which is dealing with spreading Recreational cells in a close proximity to Housing cells.

The next described scenarios were developed based on the setting parameters presented in Table 1.

2. The Nature City - In this scenario, the parameters for the Housing and Nature cells were set such that they would support the desired distribution of $\mathrm{Na}$ ture cells in the city. A clear preference was set for locating Housing cells close to Nature cells and for Nature cells to neighbor other Nature cells in order to create a Nature polygon(s).

3. The Mixed-Use City - The idea of this scenario is to mix Commercial, Housing, and Industry- $H$ cells. In order to do this, the parameters in this scenario were set such that a high score was given to Housing and Industry- $H$ cells that were located close to Commercial cells, and vice versa.

4. The Separate City-In order to create a clear separation between the Housing- $H$ cells area and the Housing- $L$ cells area, the suitability parameters were set so that Housing- $H$ cells will be close to each other and Housing- $L$ cells will be close to each other while a separation is maintained between these two kinds of Housing.

Based on the suitability parameter settings (shown in Table 1) of each planning scenario, the system allocates the required land use to cells. This results in a land-use pattern-an outline plan. This plan is used as a platform in the current study for locating facilities, as noted above.

\section{The city land-use configurations}

\subsection{The Recreation City scenario}

In the Recreation City scenario (Fig. 2), the Commercial area is located in the center of the city. The Recreation cells include one main area which is located in the center, attached to the Commercial area, and some Recreation cells that are spread across the city. In all three scenarios, the isolated Recreation cells are distributed around the central part of the city at some distance from the center. The Connected City version also includes some Nature cells that penetrate into the Housing areas. In the Connected City scenario, Housing- $L$ cells encircle the Housing- $H$ cells. In all three versions, Industry cells are located in the outer area of the city and are divided into a number of clusters. Some of these clusters are a mixture of Industry- $H$ and Industry- $L$ and some include only one kind of industry.

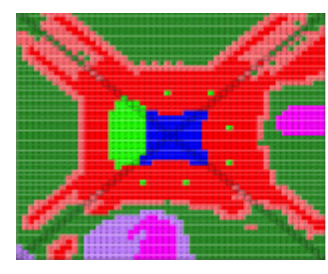

Basic City

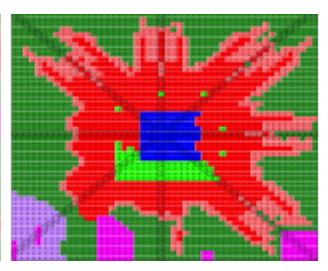

Corridor City

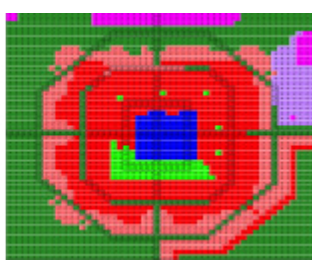

Connected City
Figure 2: The Recreation City scenario. Color code: Housing- $H$ is red; Housing- $L$ is pink; Industry- $H$ is dark purple; Industry- $L$ is light purple; Commercial is blue; Recreation is light green; Nature is dark green.

\subsection{The Nature City scenario}

In the Nature City scenario (Fig. 3), in the Basic and Corridor City forms, the Commercial area spreads out from its basic central origin and includes some mixed uses by including Housing- $H$ and Recreation cells. In addition, some Commercial cells are spread out in these city forms. On the other hand, in the Connected City, the Commercial cells are located in the central part of the city and are compact. There is no mixing with Housing- $H$ cells. The Basic City version is characterized by Industry- $L$ cells that are developed at a relatively large distance from the Housing cells. The Connected City is the only 
version that includes clusters of Nature cells in the city in addition to some separate Nature cells that are distributed throughout the area. In the two other options, the city is developed into Nature areas and the penetration of Nature cells into the Housing areas is limited and includes only a few isolated cells.

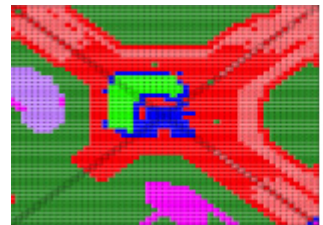

Basic City

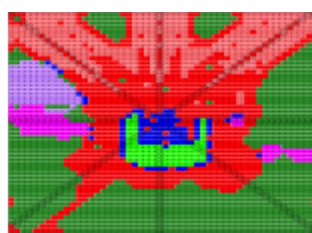

Corridor City

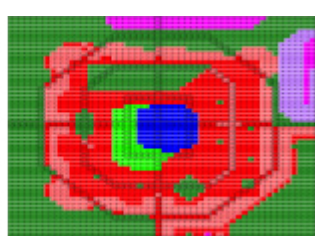

Connected City
Figure 3: The Nature City scenario. The color coding is the same as in Fig. 2 .

\subsection{The Mixed-Use City scenario}

In the Mixed-Use City scenario (Figs. $4 \mathrm{a}$ and $4 \mathrm{~b}$ ), the Connected City is characterized by a Commercial center concentrated in one area in the city center. In the Basic City and Corridor City, the Commercial cells are spread all over the city in the form of a main cluster and many individual Commercial cells. The Connected City, in contrast to the others, mixes Commercial cells and Housing- $H$ cells only in the central part of the city. Another characteristic of the Connected City is that Commercial cells only mix with Housing- $H$ cells, while in the other two city forms the Commercial cells also mix with Housing- $L$ and Industry- $H$. In all three city forms, Industry- $H$ cells are spread throughout the city with distinguished focal areas. In the Basic and Corridor forms, the focal area is located in the center. In each of the three versions there are Industry- $H$ and Housing cells that are not located in the main body of the city. The difference between the forms in this regard is in the amount and the way these cells are distributed. Note that all these differences emerge while the same settings are used for the landuse suitability function. As for Industry- $L$ cells, in all versions there is a focal area that is separate from Housing. With respect to the distribution of the Nature cells, only in the Connected City version are there some Nature cells that constitute an enclave in the Housing cell areas. In the other two city forms, the Nature cells are situated at the outskirts of the city. The fact that the Commercial cells in the Connected City version are not spread all over the city and that the mixing of these cells occurred only in the central part of the city is an interesting result in itself (Fig. 4a). However, for the sake of a comparison, this is not particularly useful since this would mean that the city forms are compared on an unequal basis in terms of mixing. Therefore, for the purpose of comparison, we artificially modified the land-use map by "planting" Commercial cells in differ- ent areas of the city (Fig. 4b). In comparing the scenarios we now replace the original Connected Mixed-Use City scenarios with the modified one displayed in Fig. 4b.

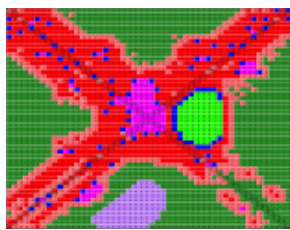

Basic City

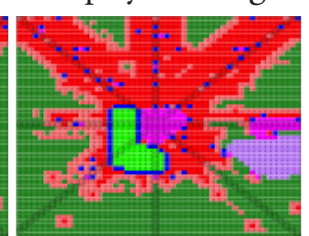

Corridor City

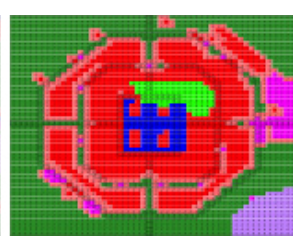

Connected City
Figure 4a: The Mixed-Use City scenario.

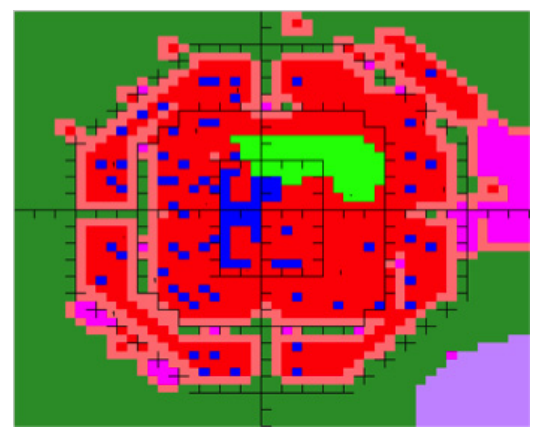

Figure 4b: The modified Connected Mixed-Use City scenario.

\subsection{The Separate City scenario}

In this scenario (Fig. 5), a central Commercial area is developed adjacent to a Recreation area in all three city forms. In addition, Housing- $L$ is a single cluster and not adjacent to Housing- $H$ cells. Industry- $H$ cells are located as two clusters in all forms. In the Connected City there are two distinct Housing areas: Housing- $H$ and Housing- $L$; in the other two forms, Housing$H$ is developed as one cluster, while Housing- $L$ cells are developed in two or more clusters. In each case they are separated from the Housing- $H$ cells.

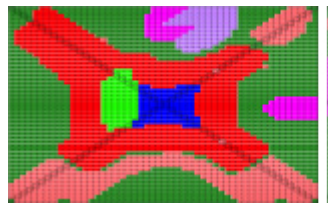

Basic City

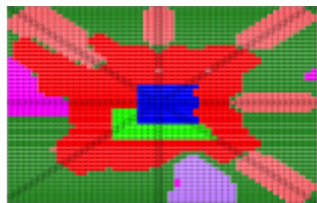

Corridor City

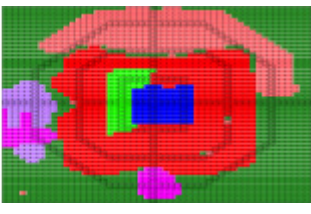

Connected City
Figure 5: The Separate City scenarios.

\section{5}

The 12 cities

These developed 12 cities, which differ in terms of land-use patterns, provide distinct settings for suppliers to locate their facilities and for individuals/households to conduct their daily activities. For each one of the city versions, the multi-agent model simulates how individuals and households organize their activities and travel in these spatial settings. The behav- 
ior of these individuals and their households generates spatial demand. Facility agents respond to this demand. The result of this interaction is a co-evolutionary process after convergence and a city with a particular distribution of facilities. This process leads to a creation of nine facility maps for each city version. Each map indicates the distribution of a certain type of facility (Arentze and Timmermans 2000). Since the focus of this study concerns global city implications which emerged from these distributions, we confined the discussion below to these global aspects.

\section{Evaluation of the 12 city plans and discussion}

We now analyze the 12 city plans/scenarios on the basis of four mobility and accessibility measures: 1) total travel distance per day, 2) number of trips per day, 3) number of facilities per distance category, and 4) distance to the first- and second-nearest facility. The comparison between the 12 scenarios is based on the outcomes of the numerical simulations and the synthetic population created in the model, which is 10 percent of the actual population.

\subsection{Mobility: Total travel and number of trips}

In terms of the estimated total travel distance, Fig. 6 clearly shows that the Connected City is significantly better than all other city forms, while the Basic form is the worst. The shortest distance among those for the connected scenarios was found for the Separate form, followed by the Recreation and MixedUse forms.

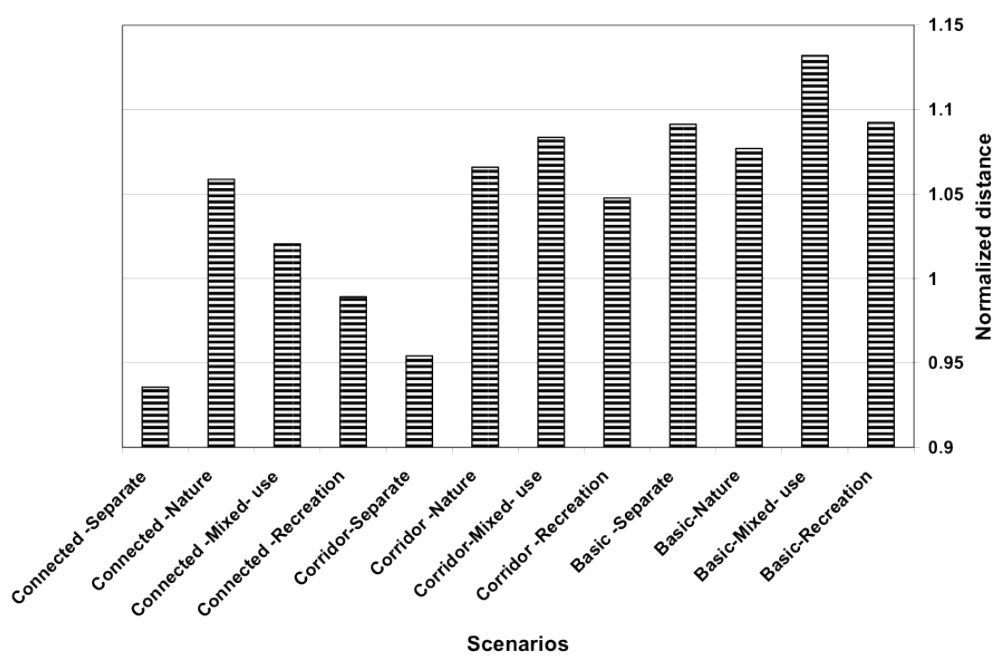

Figure 6: Normalized total travel distance per day (including walking, biking, and public transportation). It is normalized by a characteristic value.
In the Nature scenario, the effect of the Nature cells being spread throughout the city in all three city forms is an increase of travel distance. This is because the inner Nature cells cause the urban area to be spread out, leading to an increase in route length to the different facilities. On the other hand, Nature areas may be considered "green lungs" that absorb $\mathrm{CO}_{2}$ emissions. We currently do not address this aspect here, but it can be assumed that such Nature cells do not have a significant impact on other emitted pollutants from traffic, such as SOx, NOx, and particulate matter (Katoshevski et al. 2010), which are regarded as posing a health risk.

The second indicator is the number of trips made during one day. Figure 7 shows the comparison between the various scenarios on the basis of the predicted total number of trips in the city. As mentioned earlier, this indicator is associated with air pollution, because a higher number of trips, with total distance remaining constant, reflects a higher level of pollution. Ignition (engine-start) of vehicles emits relatively more pollution than the amount emitted while traveling and that is without gaining distance. The figure shows that the lower number of trips is generated for the Corridor Separate City, Connected Nature City, and Connected Separate City scenarios. Hence, combined with the findings of the total travel distance, the Connected Separate City scenario seems best in these respects. The Basic Recreation City scenario results in the lowest number of trips of all three Recreation scenarios, while the other Basic scenarios show the opposite behavior. That is, they show the largest number of trips relative to all other scenarios.

It is interesting to note that the Recreation scenario in the Basic City form shows the lowest number of trips among the scenarios of the Basic City. This fact, combined with the findings in Fig. 6, suggests that the Recreation scenario is the preferred one within the Basic City form in terms of the two indicators for air pollution emission addressed here. In the Corridor City form, there is a consistency (between the above two indicators) for the Separate scenario; that is, the Separate scenario reveals the best results in terms of pollution in the Corridor City form. 


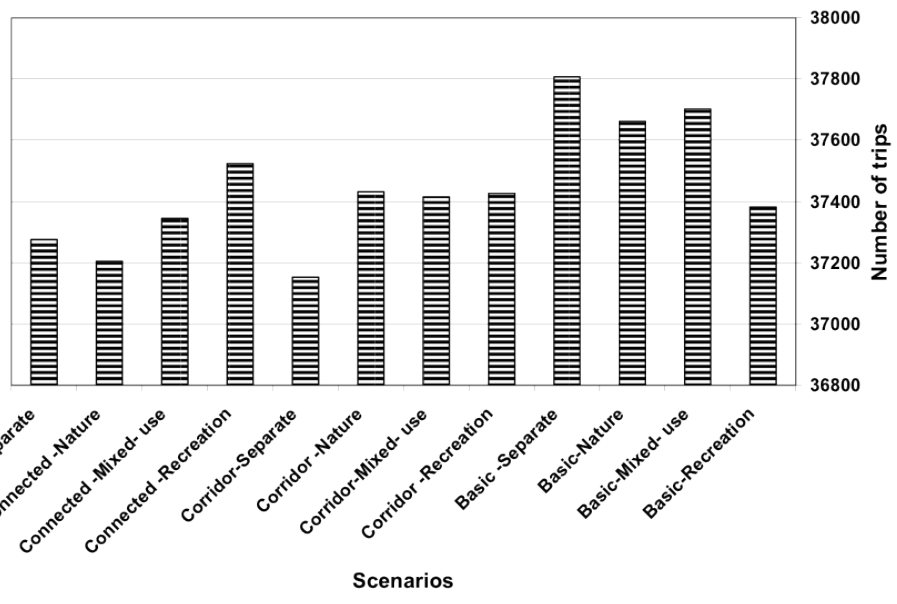

Figure 7: Number of trips per day for each of the scenarios.

\subsection{Accessibility: Number of facilities per distance category and distance to the first- and second- nearest facilities}

The accessibility indicators, the number of facilities per distance category, and the distance to the nearest facilities are assumed to influence the expected welfare of the population. Figure 8 shows the number of facilities per distance category. It demonstrates that the larger the distance, the more facilities that are available in all cities forms and scenarios. The total number of facilities for the two first distances of 500 and 750 meters is the highest for the Corridor Recreation City and the Basic Separate City scenarios, followed by the Connected Recreation City and Connected Separate City scenarios respectively. Hence, the Connected Separate City scenario once again has some relative advantages in the number of facilities in the two first distance categories. This result is in line with the former findings concerning the advantage of the Connected Separate City scenario.

The Nature scenarios, in all city forms, have the lowest number of facilities in the first two distance categories, which can be regarded as a disadvantage in terms of the variety of facilities offered by the city. The analysis shows that when comparing scenarios, the proportions between the numbers of facilities of the three distances categories (where the total number of facilities for the three distances represent 100 percent) are very similar. The differences are in the order of 2 percent (we do not present this as a graph). Thus, the relative distribution of facilities in the city is similar for all scenarios. Hence, this indicator does not differentiate between the scenarios, while the absolute number gives a better indication, as described above.

The Recreation scenario in the Corridor City form, which was ranked first in terms of the number of facilities in the closer distance categories, also has the shortest distance to the firstnearest facility, as is shown in Fig. 9. The same short distance to the first-nearest facility is also found for the Recreation scenario in the Connected City (which was ranked third before). In fact, all four scenarios for the Connected City perform well according to this indicator. The Recreation Corridor City scenario is second in terms of distance to the first-nearest facility, and the Separate Connected City scenario is third.

As for distance to the second-nearest facility, displayed in Fig. 10, the Basic Separate City scenario has the shorter distance. There are no particular advantages to any of the scenarios for the Connected City. It is interesting to note that Nature cells within the city have a profound influence in the Connected City form when comparing the distances to the first- and second-nearest facilities. On one hand, the Nature scenario in the Connected City has the shortest distance to the first-nearest facility among all Nature scenarios. On the other hand, it leads to the largest distance to the second-nearest facility in all three city forms. This effect can be attributed to the fact that the Nature cells are not distributed homogenously in the city and their concentration is larger in the outer areas of the city. The Basic Separate City scenario has the shortest total distance to the first- and second-nearest facilities, followed by the Nature Corridor City, the Recreation Connected City, and the Connected Mixed-Use City scenarios respectively.

We thus conclude that the indicators of travel distance and the number of trips enable us to choose a preferable scenario in relations to pollution emission levels. The number of facilities per distance category, when normalized for each scenario, was found to be a non-differentiating performance indicator. The absolute number of facilities provided a better way of differentiating between scenarios and urban forms. The distance to the first- and second-nearest facilities also gave a clear indication of which city plan was most preferable. 


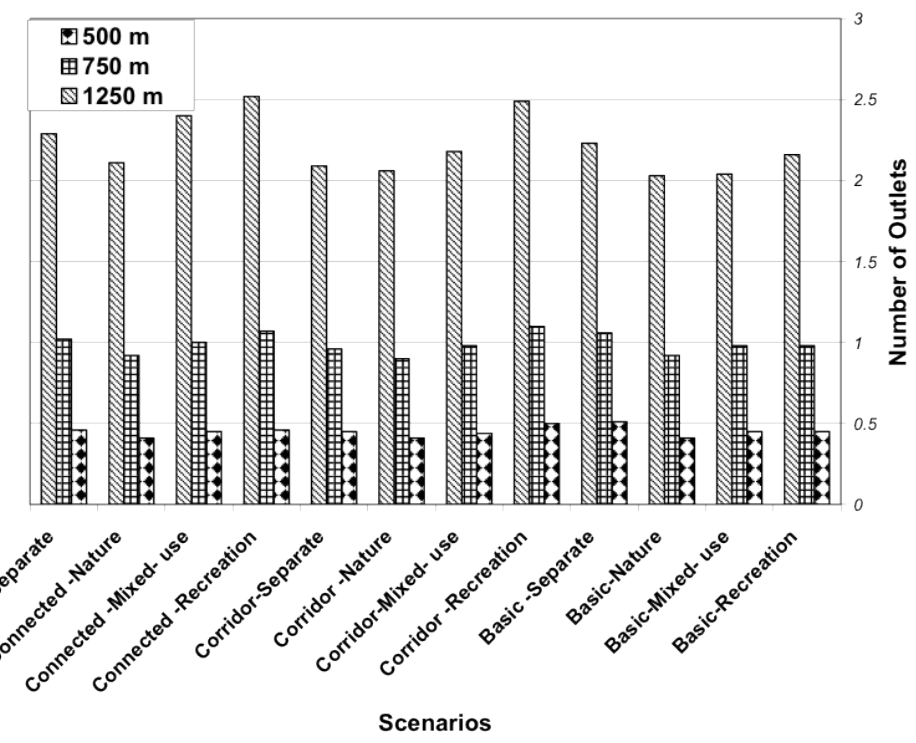

Figure 8: Number of outlets (facilities) per distance category.

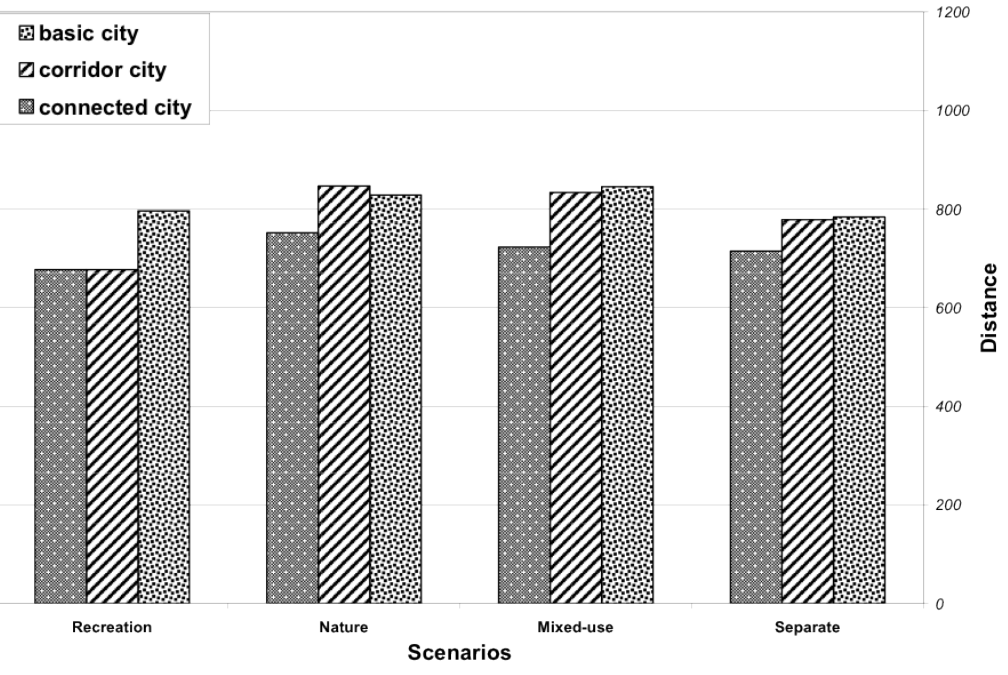

Figure 9: Distance to the first-nearest facility, average in meters.

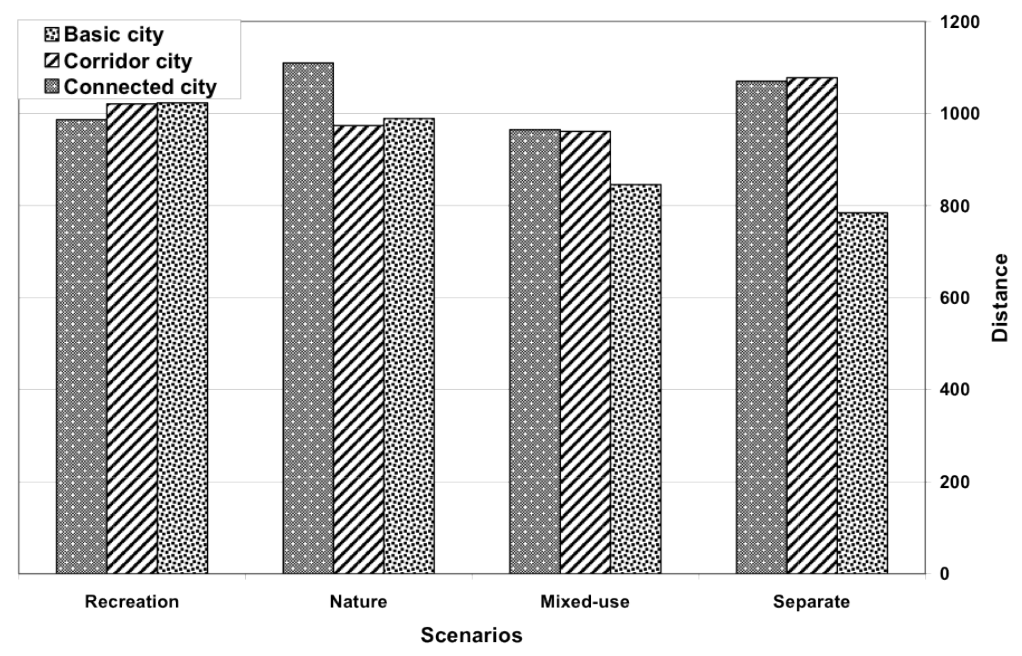

Figure 10: Distance to the second-nearest facility, average in meters.

\section{$8 \quad$ Concluding remarks}

This study examined the possible effects of different planning concepts/scenarios on the development of a city as measured in terms of a series of performance indicators related to mobility, environmental impact, and sustainability. The study is based on a planning support system that first generates basic landuse configurations that are consistent with planning norms and expert knowledge and decisions, and that are related to land-use suitability, land-use interdependencies, and user preferences. Next, a multi-agent model is used to simulate how the decisions of interacting and co-evolving agents influence the dynamic development of the city, starting from basic urban forms and planning scenarios. The features of these emerging configurations of land use and associated activity-travel patterns are then captured in terms of the performance indicators, which allow planners to gain insight into which urban forms and scenarios are most likely to generate a sustainable development.

The study, although theoretical in nature, is based on data about people's housing preferences, an agent-based model of daily activity patterns, and location choice behavior. Since the system has many parameters, it is clear that the generated outcomes are sensitive to parameter settings. On the other hand, it should also be emphasized that the conjoint model of housing preferences and the activity-based travel demand model have been calibrated on empirical data. To the extent that these models capture underlying utilities and selection mechanisms, the results can be generalized in a global sense. Detailed statistics, of course, depend on the specific configurations of land use. Rather than using more or less abstract city forms, it will be evident that a concrete city can be used as input. In that case, the agent-based models will simulate exogenous dynamics of the urban system.

Keeping these in mind, the substantive results of this study suggest that based on the performance indicators that were selected, the Corridor and Connected City scenarios performed best from among the different 12 scenarios. Thus, if the goals of planning are to reduce emissions (generated by traffic), while maintaining relatively good accessibility to facilities, these urban forms (of those considered in the study), should be the target. If the choice were the Connected City, the Separate City scenario seems to offer several advantages. Since several separated housing areas are surrounded by facilities, activity-travel patterns are characterized by relatively lower total travel distances and shorter distances to facilities, resulting in reduced emissions and higher social welfare and leading to better quality of life. 
Finally, we should emphasize that these conclusions relate to the urban forms and scenarios considered. For example, multi-nuclei forms may influence the ranking results. Future research should therefore examine other forms.

\section{References}

Algers, S. and M. Beser. 2000. SAMPERS-The new Swedish national travel demand forecasting tool. Paper presented at the IATBR Conference, Gold Coast, Australia.

Arentze, T. A. and H. J. P. Timmermans. 2000. Albatross: a learning-based transportation oriented simulation system. European Institute of Retailing and Services Studies. Eindhoven.

Arentze, T. A. and H. J. P. Timmermans. 2004. A micro-simulator of urban land use dynamics integrating a multi-agent model of land development and an activity-based model of transport demand. Proceedings of the 83rd Annual Meeting of the Transportation Research Board.

Badoe, D. A. and E. J. Miller. 2000. Transportation-land-use interaction: empirical findings in North America, their implications for modeling. Transportation Research Part $D$ 5(4): 235-263. doi: 10.1016/S1361-9209(99)00036-X.

Bagley, M N. and P. L. Mokhtarian. 2000. The impact of residential neighborhood type on travel behavior: a structural equations modelling approach. Paper presented at the XI Pan-American Conference on Traffic and Transportation Engineering, Gramado, Brazil, May 2000. doi: 10.1007/ s001680200083.

Boarnet, M.G. and S. Sarmineto. 1998. Can land-use policy really affect behavior? Urban Studies 35(7): 1155-1169. doi: 10.1080/0042098984538.

Crane, R. and R. Crepeau. 1998. Does neighborhood design influence travel? A behavioral analysis of travel diary and GIS data. Transportation Research Part D 3: 225-238. doi: 10.1016/S1361-9209(98)00001-7.

Cervero, R. 1989. America's Suburban Centers: The Land UseTransportation Link. London: Allen and Unwin.

Cervero R., and K. Kockelman. 1997. Travel demand and the 3Ds: density, diversity and design. Transportation Research Part D 2(3): 199-219. doi: 10.1016/S13619209(97)00009-6.

Central Bureau of Statistics. 1995. Time-use in Israel: time budget survey 1991/1992. Research Report Special Series 996. Central Bureau of Statistic, Jerusalem.

de Nijs, T. C. M., R. de Niet, and L. Crommentuijn,. 2004. Constructing land-use maps of the Netherlands in 2030. Journal of Environmental Management 72(1-2): 35-42. doi: 10.1016/j.jenvman.2004.03.015.Dunphy, R., and K. Fisher. 1996. Transportation, congestion and density: New insight. Transportation Research Record 1552: 89-96. doi: 10.3141/1552-12.

Geurs, K. T., and B. Van Wee. 2006. Ex-post evaluation of thirty years of compact urban development in the Netherlands. Urban Studies 43(1): 139-160. doi: 10.1080/00420980500409318.

Gunn, H. F. and A. Van der Hoorn. 1998. The predictive power of operational demand models. Proceedings of the Seminar Transportation Planning Methods, European Transport Conference. London: Loughborough University.

Forkenbrock, D. J., and L. A. Schweitzer. 1999. Environmental justice in transportation planning. Journal of the American Planning Association 65(1): 96-111.

Frank, L., and G. Pivo. 1994. Impact of mixed use and density on utilization of three models of travel: single-occupant vehicle, transit and walking. Transportation Research Record 1466: 44-52.

Hall, P. 1996. The future of the metropolis and the form. Regional Studies 33(3): 211-220. doi: 10.1080/00343400701232314.

Handy, S. 1996. Understanding the link between urban form and nonwork travel behaviour. Journal of Planning Education Research 15(3): 183-198. doi: 10.1177/0739456X9601500303.

Holtzclaw, J. 1990. Manhattanization versus sprawl: low density impacts auto use comparing five bay area communities. In Proceedings of the 11th International Pedestrian Conference, 99-106. Boulder, Colorado.

Katoshevski, D., M. Ruzal, T. Shakked, and E. Sher. 2010. Particle grouping, a new method for reducing emission of submicron particles from Diesel engines. Fuel 89: 2411 2416. doi: 10.1016/j.fuel.2010.04.001.

Katoshevski-Cavari, R., T. A. Arentze, and H. J. P. Timmermans. 2009. A computerized tailor made plan: can that be a tool for achieving public interest in planning. GRF 29: 26-47.

Kitamura, R., E. I. Pas, C. V. Lula, T. K. Lawton, and P. E. Benson. 1996. The sequenced activity mobility simulator (SAMS): an integrated approach to modeling transportation, land-useand air quality. Transportation 23(3): 267291. doi: 10.1007/BF00165705.

Kitamura, R., P. Mokhtarian, and L. Laidet. 1997. A microanalysis of land-use and travel in five neighborhoods in the San Francisco Bay area. Transportation 24(2): 125-128. doi: 10.1023/A:1017959825565.

Marquez, L. O, and N. C. Smith. 1999. A framework for linking urban form and air quality. Environmental Modelling 
and Software 14: 541-548.

Newman, P., and J. Kenworthy. 1989. Gasoline consumption and cities: a comparison of US cities with a global survey. Journal of the American Planning Association 55(1): 24-37. doi: 10.1080/01944368908975398.

Newman, P.W. G., and J. R. Kenworthy. 1992. Is there a role for physical planners? Journal of the American Planning Association 58(3): 353-362. doi: 10.1080/01944369208975814.

Newman, P., and J. Kenworthy. 1999. The cost of automobile dependence: a global survey of cities. Transportation Research Record 1670. Washington, DC: Transportation Research Board.

O’Meara, M. 1998. How mid-sized cities can avoid strangulation. World Watch Sep/Oct.: 8-15.

O'Meara Sheehan, M. 2001. Planning cities for less cars. United Nations Chronicle 38(1): 52-53.

Pontes de Aquino, A. and H. J. P. Timmermans. 2010. The built environment as a décor of unfolding housing careers and activity-travel patterns: reflection and research agenda. Paper presented at the WCTR Conference, Lisbon, Portugal.

Preimus, H. 1999. Sustainable cities: how to realize an ecological breakthrough: a Dutch approach. International Planning Studies 4(2): 213-236.

Roorda, M. J., J. A. Carrasco, and E. J. Miller. 2009. An integrated model of vehicle transactions, activity scheduling and mode choice. Transportation Research B 43: 217-229. doi: 10.1016/j.trb.2008.05.003.

Rossi, T, and Y. Shiftan. 1997. Tour-based travel demand modeling in the U.S. In Proceedings of the 8th IFAC/IFIP/IFORS Symposium on Transportation Systems. Chania, Greece.

Salvini, P, and E. J. Miller. 2005. ILUTE: An operational prototype of comprehensive microsimulation model of urban systems. Networks and Spatial Economics 5: 217-234. doi: 10.1007/s11067-005-2630-5.

Shiftan, Y. 1999. A practical approach to model trip chaining. Transportation Research Record 1945: 17-23.

Shiftan, Y. 2000. The advantage of activity-based modeling for air-quality purposes: theory versus practice and future needs. Innovations 13(1): 95-110.
Shiftan, Y. 2008. The use of activity-based modeling to analyze the effect of land-use policies on travel behaviour. Annals of Regional Science 42: 79-97. doi: 10.1007/s00168-0070139-1.

Stone, B., A. C. Mednick, T. Holloway, and S. N. Spak. 2007. Is compact growth good for air quality? Journal of the American Planning Association 73: 404-420. doi: $10.1080 / 01944360708978521$.

Waddell, P. 2002. UrbanSim: Modeling urban development for land use, transportation, and environmental planning. Journal of the American Planning Association 68(3): 297314. doi: 10.1080/01944360208976274. 